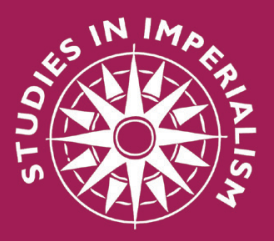

\title{
JUTE AND EMPIRE
}

\section{The Calcutta Jute Wallahs and the Landscapes of Empire}

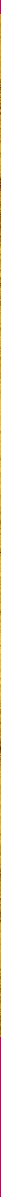




\section{IMPERIALS INM}

General editor John M. MacKenzie

When the 'Studies in Imperialism' series was founded by Professor John M. MacKenzie more than thirty years ago, emphasis was laid upon the conviction that 'imperialism as a cultural phenomenon had as significant an effect on the dominant as on the subordinate societies'. With well over a hundred titles now published, this remains the prime concern of the series. Cross-disciplinary work has indeed appeared covering the full spectrum of cultural phenomena, as well as examining aspects of gender and sex, frontiers and law, science and the environment, language and literature, migration and patriotic societies, and much else. Moreover, the series has always wished to present comparative work on European and American imperialism, and particularly welcomes the submission of books in these areas. The fascination with imperialism, in all its aspects, shows no sign of abating, and this series will continue to lead the way in encouraging the widest possible range of studies in the field. Studies in Imperialism is fully organic in its development, always seeking to be at the cutting edge, responding to the latest interests of scholars and the needs of this everexpanding area of scholarship.

\section{Jute and empire}

\section{MANCHESTER 1824}

Manchester University Press 


\section{-STUDIES IN-
IMPERIALISM}

Western medicine as contested knowledge ed. Andrew Cunningham and Bridie Andrews

Unfit for heroes

Reconstruction and soldier settlement in the Empire between the wars Kent Fedorowich

\section{Empire and sexuality}

The British experience

Ronald Hyam

'An Irish Empire!'

Aspects of Ireland and the British Empire ed. Keith Jeffery

The empire of nature

Hunting, conservation and British imperialism John M. MacKenzie

Propaganda and empire

The manipulation of British public opinion, 1880-1960

John M. MacKenzie

Imperialism and popular culture

ed. John M. MacKenzie

Gender and imperialism

Clare Midgley

Colonial masculinity

The 'manly Englishman' and the 'effeminate Bengali' Mrinalini Sinha

The imperial game

Cricket, culture and society

ed. Brian Stoddart and Keith A. P. Sandiford

The French empire at war, 1940-45

Martin Thomas

Travellers in Africa

British travelogues, 1850-1900

Tim Youngs 


\section{Jute and empire The Calcutta Jute Wallahs and the Landscapes of Empire}

Gordon T. Stewart

MANCHESTER

UNIVERSITY PRESS

Manchester 
Copyright @ Gordon T. Stewart 1998

The right of Gordon T. Stewart to be identified as the author of this work has been asserted by him in accordance with the Copyright, Designs and Patents Act 1988.

Published by MANCHESTER UNIVERSITY PRESS

ALTRINCHAM STREET, MANCHESTER, M1 7JA, UK

www.manchesteruniversitypress.co.uk

British Library Cataloguing-in-Publication Data

A catalogue record for this book is available from the British Library

Library of Congress Cataloging-in-Publication Data applied for

ISBN 0719054397 hardback

First published 1998

$505030201009998 \quad 10987654321$

The publisher has no responsibility for the persistence or accuracy of URLs for any external or third-party internet websites referred to in this book, and does not guarantee that any content on such websites is, or will remain, accurate or appropriate.

Typeset in Trump Medieval

by Northern Phototypesetting Co Ltd, Bolton 